\title{
Rinossinusite Aguda complicada com Empiema Meníngeo - Relato de Caso.
}

\author{
Joana Carolina Junqueira de Brum'; Rômulo Gomes da Silveira1; \\ Barbára Fontes Macedo1; Lucas Schaefer'; Rafaela Brambilla1; \\ Diego Antônio Fagundes².
}

\section{Resumo}

Introdução: rinossinusite bacteriana (RSB) é uma doença infecciosa comum, na maioria dos casos possui resolução espontânea. Contudo, o clínico deve estar atento ao reconhecimento precoce de complicações intracranianas (CIC), visto que há possibilidade de desfechos fatais. O objetivo deste trabalho visa abordar a detecção precoce de complicações neurológicas da RS que possuem alta morbimortalidade. Método: relato de caso de um paciente com empiema extradural de RS bacteriana.

Resultados: 15 anos, masculino, previamente hígido, com quadro de RS há 6 dias, procurou atendimento por febre, dor retrorbitária e edema periocular à esquerda, associado a secreção nasal piossanguinolenta. Iniciado amoxicilina com ácido clavulânico endovenoso. Após 2 dias evoluiu com piora do sensório, afasia de expressão, hipotonia muscular generalizada, incapacidade de deambular e rigidez nucal. Transferido para centro de tratamento intensivo e iniciado antibioticoterapia empírica com ceftriaxone, vancomicina e metronidazol. Solicitada tomografia computadorizada de crânio (TCC), demonstrando coleção líquida extra-axial junto a porção anterior da fissura inter-hemisférica predominantemente à esquerda. Após, foi realizada angioressonância magnética do crânio que evidenciou empiema extradural em região frontal e descartou trombose de seio venoso (TSV). Análise liquórica realizada sugestiva de meningite bacteriana com cultura do líquor negativa. Foi necessário desbridamento cirúrgico dos seios paranasais (SPN) com coleta de material para cultura: crescimento de Staphylococcus

\footnotetext{
${ }^{1}$ Médico(a) residente do programa de pós-graduação em Medicina Interna da Universidade Luterana do Brasil. joanacjunqueira@gmail.com

${ }^{2}$ Medicina Interna e Neurologia no Hospital Universitário de Canoas. diegoafag@hotmail.com
} 
aureus. Após realização da antibioticoterapia por 28 dias, o paciente recebe alta com resolução dos sintomas. Conclusões: As CIC da RS ocorrem pela extensão do processo infeccioso por contiguidade ou via hematogênica, podendo evoluir para meningite, meningoencefalite, empiema meníngeo sub ou extradural até abscessos cerebrais. A apresentação pode ocasionar desde cefaléia até hemiparesias, convulsões e rebaixamento de sensório. Vale ressaltar que $50 \%$ das culturas do líquor são estéreis, sendo indicada coleta de material durante drenagem cirúrgica dos SPN para auxílio na escolha da terapia antimicrobiana. O diagnóstico é dado pela suspeição clínica, associada a TCC, entretanto a angioressonância deve ser realizada posteriormente para melhor avaliação e para descartar TSV. Antibioticoterapia de amplo espectro por 4-8 semanas deve ser instituída além de abordagem cirúrgica para drenagem da secreção.

Palavras Chave: rinossinusite; complicações neurológicas da rinossinusite; empiema meníngeo.

\section{Acute rhinosinusitis complicated with empyema meningeal - A Case Report.}

\section{Abstract}

Introduction: bacterial rhinosinusitis (RSB) is a common infectious disease in most cases have spontaneous resolution. However, the clinician should be aware of the early detection of intracranial complications (ICC), since there is possibility of fatal outcomes. This study aims to address the early detection of neurological complications of RS who have high morbidity and mortality. Method: case report of a patient with epidural empyema of bacterial RS. Results: 15, male, previously healthy, with rhinosinusitis 6 days, sought treatment for fever, retro-orbital pain and periocular edema left piossanguinolenta associated with nasal discharge. Amoxicillin with clavulanic acid intravenously. After 2 days progressed with worsening of sensory aphasia, expression, generalized muscular hypotonia, were incapable of walking and nuchal rigidity. Transferred to intensive care and started empiric antibiotic therapy with ceftriaxone, vancomycin and metronidazole. Requested cranial computed tomography (CCT), 
demonstrating extra-axial fluid collection along the anterior portion of the interhemispheric fissure predominantly left. After, magnetic resonance angiography of the skull was performed which showed extradural empyema in frontal and ruled venous sinus thrombosis (VST). Liquor analysis suggestive of bacterial meningitis with negative cerebrospinal fluid culture. It was necessary surgical debridement of the paranasal sinuses (PNS) with collection of material for culture: growth of Staphylococcus aureus. After completion of antibiotic therapy for 28 days, the patient is discharged with resolution of symptoms. Conclusions: CIC of RS occur by the extent of the infection by contiguity or hematogenous, and may progress to meningitis, meningoencephalitis, meningeal sub empyema extradural or even brain abscesses. The presentation may result from headache to hemiparesis, seizures and sensory relegation. It is noteworthy that $50 \%$ of liquor cultures are sterile, and indicated collecting material for surgical drainage of PNS to aid in the choice of antimicrobial therapy. The diagnosis is given by clinical suspicion, associated with TCC, however angioresonance should be performed later for better assessment and to rule VST. Broad spectrum antibiotic therapy for 4-8 weeks should be established in addition to surgical approach for drainage of secretions.

Keywords: rhinosinusitis; neurological complications of rhinosinusitis; empyema meningeal. 


\section{Referências}

BRUNER, D.I.; LITTLEJOHN, L.; PRITCHARD, A. Subdural Empyema Presenting with Seizure, Confusion, and Focal Weakness. West J Emerg Med. 2012;13:509-511.

MILOUNDJA, J.; BAMBA, J.S.; MOUBA, J.F.; ELLA ONDO, T.; MWANYOMBET, L.; MANDJI LAWSON, J.M.; N'ZOUBA, L. Cranioencephalic complications of bacterial sinusitis in children and adolescents: eight cases in Libreville (Gabon). Sante. 2011; 21(4):215-20.

KHARRAT, S.; SAHTOUT, S.; ZAININE, R.; DRIDI, I.; TEMIMI, S.; BELTAIEF, N.; BESBES, G. Intracranial complications of sinusitis. Tunis Med. 2011; 89(6):534-8.

YEH, C.H.; CHEN, W.C.; LIN, M.S.; HUANG, H.T.; CHAO, S.C.; LO, Y.C.

Intracranial brain abscess preceded by orbital cellulitis and sinusitis. J Craniofac Surg. 2010;21(3):934-6.

POULOPOULOS, M.; FINELLI, P.F. Neurological complications with acute sphenoid sinusitis a surgical emergency? Neurocrit Care. 2007;7(2):169-71. 